$10-2019$

\title{
Catholic Heritage, Ethno-Racial Self-Identification, and Prejudice Against Haitians in the Dominican Republic
}

Cristian L. Paredes

Loyola University Chicago, cparedes@luc.edu

Follow this and additional works at: https://ecommons.luc.edu/soc_facpubs

Part of the Sociology Commons

Author Manuscript

This is a pre-publication author manuscript of the final, published article.

\section{Recommended Citation}

Paredes, Cristian L.. Catholic Heritage, Ethno-Racial Self-Identification, and Prejudice Against Haitians in the Dominican Republic. Ethnic and Racial Studies, 42, : 2143-2166, 2019. Retrieved from Loyola eCommons, Sociology: Faculty Publications and Other Works, http://dx.doi.org/10.1080/

01419870.2018.1532097

This Article is brought to you for free and open access by the Faculty Publications and Other Works by Department at Loyola eCommons. It has been accepted for inclusion in Sociology: Faculty Publications and Other Works by an authorized administrator of Loyola eCommons. For more information, please contact ecommons@luc.edu. cc) (i) $\ominus$

This work is licensed under a Creative Commons Attribution-Noncommercial-No Derivative Works 3.0 License. (c) Taylor \& Francis, 2019. 


\title{
Catholic heritage, ethno-racial self-identification, and prejudice against Haitians in the Dominican Republic
}

\author{
Cristian L. Paredes ${ }^{1}$ \\ Department of Sociology and Latin American and Latinx Studies Program, Loyola University \\ Chicago, Chicago IL, USA
}

\begin{abstract}
Latin American cultures are significantly influenced by Catholicism, which partially but meaningfully represents the European legacy that situates Latin American societies into the Western world. This influence may be particularly relevant in the Dominican Republic, where local discourses have underlined the role of Catholicism as an essential characteristic of the Dominican identity. In this study, I use nationally- and regionally-representative survey data to examine whether Catholic self-identification is directly associated with self-identifications that downplay individuals' own Afro characteristics, and whether individuals who self-identify as Catholic are significantly prejudiced against Haitians. I find regional-level evidence of direct associations between Catholic self-identification and self-identifications that downplay Afro characteristics. I also find national- and regional-level evidence of direct associations between Catholic self-identification and different indicators of prejudice against Haitians. These findings reveal the prevailing influence of Catholicism on ethno-racial self-identification and anti-Haitian sentiment in the Dominican Republic.
\end{abstract}

ARTICLE HISTORY Received 23 October 2017; Accepted xx September 2018

\section{Keywords}

Catholicism; ethno-racial identities; prejudice against Haitians; Dominicanidad and mestizaje; Latin America

"Voodoo, Santería, African Superstitions are uprooting the Catholic religion that, like language and race, distinguishes our nationality."

Mario Vargas Llosa (2003 [2001]), The Feast of the Goat

Catholicism is a major cornerstone of Latin American cultures, values, and norms.

Inherited from Spanish and Portuguese colonialisms, Catholicism partially but meaningfully represents the European legacy that situates Latin American societies into the Western world.

${ }^{1}$ Cristian Paredes: cparedes@luc.edu 
Catholicism brought not only a major religious doctrine, but also frameworks of authority composed of norms and policies of citizenship that severely punished nonconformity, and that justified colonialist initiatives (Fredrickson 2003). These norms and policies served to underline the otherness of indigenous individuals and Afro-descendants who were commonly depicted as impious savages (Flórez-Estrada 2008; Pérez Memén 2010). Although the influence of Catholic frameworks of authority on governments after colonial independence became weaker, it did not disappear, and it was notably conspicuous in several Latin American societies.

The discourses promoted by Dominican Republic's dictator Rafael Trujillo represent a noteworthy example of this influence. These discourses underline the role of Catholicism and Hispanidad -Spanish heritage- as essential components of the Dominican identity for political purposes (Sáez 1988). As narrated by Mario Vargas Llosa in his historical novel The Feast of the Goat, Trujillo justified the slaughtering of thousands of Haitians with ideological depictions of the Haitian as a threat against Catholicism and the Dominican identity (Duany 2006; Howard 2001; Sagás 2000). These depictions reinforced the pervasiveness of prejudice against Haitians and blackness in general, as well as the foundation of Dominican mestizaje ideologies (Candelario 2007; Howard 2001; Torres-Saillant 1998; Simmons 2005). ${ }^{1}$

In this study, I investigate whether the influences of the Catholic legacy on contemporary mainstream understandings of ethno-racial identities and local ethno-racial relations are significant in the Dominican Republic. I specifically intend to answer two research questions: (1) Do individuals who self-identify as Catholic self-identify more using categories that implicitly downplay their own Afro characteristics compared to non-Catholics? ${ }^{2}$ (2) Are individuals who self-identify as Catholic significantly more prejudiced against Haitians compared to non-Catholics? Although the Dominican state is secular according to its 
constitution, the influence of the Catholic hierarchy on government issues and policy-making is still significant (Riggio 2015). ${ }^{3}$ Further, more than a half of Dominicans self-identify as Catholic (Betances 2009; see Appendix).

Catholic self-identification is defined as the affinity of individuals with Catholicism whether they are practicing Catholics or merely nominal Catholics. Identification with Catholicism might serve as a culturally legitimate whitening resource to validate Dominicans' hybrid ethno-racial classifications. Moreover, Catholic beliefs might foster conservative views that condemn non-Catholic religious practices, particularly those associated with syncretic Haitian religious rituals (Howard 2001; Torres-Saillant 1998). Furthermore, public declarations of conservative Catholic authorities might exacerbate anti-Haitian sentiments (Horn 2010; Vargas Llosa 2013).

In contrast, progressive Catholic views -see Betances (2009); Wiarda (1965)- could have lessened the prevalence of prejudice against Haitians. These views, founded on beliefs derived from concerns about social justice addressed with the principles of the Catholic doctrine (e.g., liberation theology), have countered Catholic conservative perspectives to a certain extent. Several Catholic projects that work for the defence of the rights of Haitian migrants exemplify an alternative way of understanding Catholic praxis among nominal and practicing Catholics. ${ }^{4}$ Regardless of the declarations of conservative Catholic authorities, Dominicans probably acknowledge the role of Catholic priests as social conflict solvers (Betances 2009). Consequently, they may believe that commitment with social justice is a common feature of the Catholic Church. Alternatively, secular perspectives brought about by unexamined dynamics of urbanization and modernity could have contributed to shaping the contemporary mainstream Dominican identity. 


\section{The influence of Catholicism on Dominicanidad}

Dominican mestizaje ideologies have promoted Dominicanidad ("Dominican-ness"): the beliefs that emphasize the cultural foundations of the national Dominican identity (Howard 2001; Morgan 2018; Sagás 2000). Dominicanidad discourses have celebrated and overvalued its Spanish heritage, have insufficiently recognized the importance of Afro-Dominican heritage, and have embraced ethno-racial hybridity -mestizaje understood as ethno-racial mixture embodied by individuals (Paredes 2017, 2018)- in conflictive ways. As in other Latin American countries, the predominantly white elites have endorsed Spanish heritage and Catholicism as the cultural backbone of the mainstream Eurocentric stance (Howard 2001; Torres-Saillant 1998).

The meaning of Dominicanidad has been established with respect to its neighbour Haiti. Both countries are interdependent and underdeveloped, but the Dominican Republic has enjoyed a better economic situation and standard of living compared to the extremely impoverished Haiti (Winters and Derrell 2010). Despite several overlooked cases of cohesion and cooperation (Martínez 2003; Torres-Saillant 1998), Haitians historically have represented a threat for Dominicans. Currently, Haitians and their descendants systematically endure institutional and everyday racism, lack basic access to citizenship rights, and are significantly exposed to poverty and violence in the Dominican Republic (Martínez and Wooding 2017; Morgan 2018; Wooding and Petrozziello 2013).

Prejudice against Haitians is rooted in the negative depictions of Afro individuals supported by the notions of authority and virtue of the Catholic Church during colonial times (Pérez Memén 2010). Beyond anti-Haitian sentiments, the Catholic clergy participated actively in the Dominican independence from Haiti during the period of unification in the nineteenth century. ${ }^{5}$ During this period, the Haitian government confiscated the properties of the Catholic 
Church, forced the clergy to abide by the liberal Haitian constitution, and closed down the University of Santo Domingo, which was managed by Catholic authorities (Betances 2009). After the independence, Dominicans gradually strengthened their identification with Spanish heritage as a central component of Dominicanidad (Mayes 2014).

In the twentieth century, Trujillo's regime systematically disseminated Dominicanidad discourses that promoted national unity derived from Hispanidad. These discourses constituted a racial project (Omi and Winant 1994): the reproduction of racial ideologies orchestrated by the government, the elites, and, in this case, the Catholic hierarchy with the purpose of integrating individuals who shared different degrees of Spanish heritage, and excluding those who did not fit in. Trujillo and the Catholic Church developed a mutually beneficial relationship during the regime. Trujillo took advantage of the influence of the Church on Dominicans and local elites. The Catholic Church developed into a stronger and more modern institution with more dioceses, parishes, schools, and religious communities (Betances 2009). The regime reinforced the supremacy of Hispanidad supported by Catholic traditions and values as distinctive of Dominicanidad over the otherness of Haitians associated with their French heritage, the impiousness of their syncretic beliefs, and their blackness (Candelario 2007; Sáez 1988; Wiarda 1965). This racial project is particularly relevant as the foundation of an authoritarian nationalism imposed by the state and elites onto Dominicans (Howard 2001; Sagás 2000). ${ }^{6}$

Anti-Haitian sentiments debased the value of blackness to the extent that mainstream Dominicanidad discourses downplayed the relevance of Afro characteristics as distinctive of the Dominican identity regardless of their pervasiveness in local cultures and in the Afro phenotypic traits of Dominicans (Candelario 2007; Sagás 2000; Simmons 2005; Torres-Saillant 1998). Accordingly, many Dominicans with different degrees of Afro phenotypic traits self-identify 
using classifications that downplay their own Afro characteristics by highlighting their hybridity regardless of how they are perceived by others. Dominicans recognize their hybridity using an array of ethno-racial terms that are organized in schemas: sets of ethno-racial categories and their rules for how these categories are meaningful in a specific society (Roth 2012). Hybrid ethnoracial conditions are notably evident in the continuum racial schema, which organizes these conditions -locally identifiable by informal categories such as jabao, trigueño, piel canela, moreno- according to relative differences by physical and cultural traits such as region (Wheeler 2015). These differences have a significant impact on the opportunities and experiences of Dominicans (Candelario 2007; Roth 2012, 2013).

For instance, the popular term mulato acknowledges the conflictive embodiment of Afro and white racial heritages. According to mainstream Dominicanidad discourses, the meaning of mulato blames its Afro traits as the result of "Haitian atrocities during the occupation" (Howard 2001: 28). The term indio -commonly understood as a colour category rather than as an ethnic characteristic- is still popularly used by Dominicans with Afro traits in ambiguous ways instead of mulato (Candelario 2007; Duany 2006; Sagás 2000). ${ }^{7}$ Dominicans may embrace the value of Afro heritages using alternative schemas that are not advocated by mainstream discourses (e.g., transnational schemas, progressive redefinitions of mulataje; see Ricourt 2016; Roth 2013; Simmons 2005). However, mainstream discourses have inculcated Dominicans with norms for identity formation that promote the softening of their Afro traits. ${ }^{8}$

It is necessary to mention that ethno-racial identification categories in the Dominican Republic are complex, fluid, and ambiguous as in other mestizaje contexts (García-Peña 2015; Roth 2013; Wheeler 2015). Accordingly, the binary distinction between identifications that downplay Afro characteristics and identifications that openly embrace Afro characteristics does 
not intend to suggest/imply that ethno-racial identifications are well-defined and fixed. This analytically relevant distinction is useful to examine whether Catholic self-identification is significantly associated to identifications that downplay Afro characteristics while we consider phenotype captured by skin colour as another ethno-racial characteristic. In this way, the estimate of this association is obtained net of the impact of physical appearance on ethno-racial self-identification. Furthermore, I regard the hybrid/mestizo ethno-racial condition -the individually embodied mixture of traits: self-identification and skin colour- as multidimensional. This approach is useful to capture in the analyses the complexity of ethno-racial hybridity with more than one indicator (Paredes 2017, 2018).

Due to the legitimation of Catholicism as a core component of Dominicanidad, Catholic affiliation may serve as a meaningful cultural resource for self-identifying with classifications that downplay Afro characteristics. Individuals may justify their Spanish ancestry by displaying their Catholic affiliation as evidence of their Dominicanidad. They are Catholic because their ancestors kept formal traditions and values. As suggested above, they do not necessarily have to practice Catholicism; they can merely be nominal Catholics who keep family traditions without any spiritual or civic commitments associated with religious beliefs.

H1: Individuals who self-identify as Catholic self-identify more with classifications that downplay their own Afro characteristics compared to non-Catholics.

Moreover, Dominicanidad is founded not only on the Spanish heritage that justify its Western Eurocentrism, but also on its Catholic traditions and perspectives, which disapprove the syncretic religious practices of Haitians (Duany 2006; Howard 2001; Wigginton 2010). Although syncretic rituals are also part of Dominican culture, Dominicanidad discourses attribute Vodou to the presence of Haitians in their territory (Martínez 2003; Ricourt 2016). Not 
only has the Dominican Catholic Church severely criticized syncretic forms of Catholic worship, it has also played a significant role in shaping public opinion during and after Trujillo's regime. Although there are critical stances that reflect debates between progressive versus conservative tendencies within the Catholic Church, the Catholic hierarchy has aligned with the Dominican status quo in order to be politically influential even when it has officially kept a non-partisan position (Betances 2009; Horn 2010; Wiarda 1965).

This alignment is currently evident, for instance, in the position of certain members of the Catholic hierarchy against Haitian immigration. A recent example is the support of the illegalization of undocumented Dominicans of Haitian descent openly expressed by Cardinal Nicolás de Jesús López Rodríguez, who also insulted Mario Serrano, Jesuit Priest, for advocating the citizenship rights of these Dominicans (Religión Digital 2014; Vargas Llosa 2013). Bigoted declarations of powerful conservative Catholic authorities may influence public opinion against Haitians among individuals who self-identify as Catholic. This influence may be direct as recognized leaders of public opinion; or indirect, through the influence these authorities have over the priests and parishioners under their supervision.

H2: Individuals who self-identify as Catholic are more prejudiced against Haitians compared to non-Catholics.

\section{Data and methods}

The data used in this study come from two sources: the 2010 America's Barometer by the Latin American Public Opinion Project (LAPOP), a national probability sample of 1,500 adult Dominicans; and the 2010 San Benito survey (Sana, Stecklov, and Weinreb 2016), a regional, experimental random sample of 1,207 adult women. The self-weighted LAPOP survey was carried out using a multi-stage national probability sample design of voting-age adults 
considering stratification and clustering. The 2010 LAPOP survey included an additional module for gathering information about ethnic and racial characteristics and issues designed by the Project on Ethnicity and Race in Latin America (PERLA) at Princeton University.

San Benito (fictitious name) is a small urban area in the Northwestern Dominican sierra relatively close to the Haitian border, where, according to the local news, the Haitian presence is depicted as a threat. Thirty Dominican female interviewers conducted the survey. Twenty-four of them were from San Benito, and six were professional interviewers from Santo Domingo. Only one woman per house was interviewed. If more than one woman was eligible, the respondent was randomly chosen. The questionnaire was designed to gather information about several sociodemographic topics including questions about attitudes toward stigmatized populations, and individual ethno-racial characteristics. Interviews for both surveys were conducted in Spanish.

\section{Dependent variables}

The first dependent variable captures the distinction between identifications that downplay Afro characteristics (hereafter DAC identifications) and identifications that openly embrace Afro characteristics (hereafter Afro identifications). In the LAPOP survey, respondents were asked whether they consider themselves as a persona blanca (white), mestiza or india (in one category), negra (black), mulata, Afro-Dominicana, or other. I discarded observations of respondents who self-identify as other (21 observations) as well as the missing values (17 observations) from the sample. I created an Afro dichotomous variable by collapsing options negra and Afro-Dominicana (only two observations of the latter) in one category, and the other options in a category for DAC. 
In the San Benito survey, the ethno-racial self-identification question was open: "How would you define your skin colour?" Although the question did not ask for ethno-racial selfidentification using any official categories, the answers reflected the significance of the continuum racial schema with several terms for hybrid conditions. I created a binary variable by collapsing all the terms that explicitly referred to the Afro condition (negro, prieto, oscuro, moreno) in one category, and the rest of terms that explicitly or implicitly referred to a hybrid or white condition (e.g., indio, blanco claro, mulato, jabao, trigueño, canela, etc.) in another category (see Candelario 2007 for racial types). ${ }^{9}$

The second and third dependent variables capture different dimensions of national-level prejudice against Haitians using the LAPOP data. The questions are: "To what extent do you agree with the Dominican citizenship of Dominican Republic-born children of Haitian immigrants?," and "To what extent do you agree or disagree with the Dominican government granting work permits to undocumented Haitians who live in the Dominican Republic?"10 Respondents were asked to use an ordinal scale from one to seven to answer both questions: one for strongly disagree and seven for strongly agree. I dichotomized these variables in this analysis due to their non-normal distributions. I recoded values five, six, and seven as zero (agree), and values one, two, three, and four as one (do not agree). ${ }^{11}$

The fourth and fifth dependent variables measure prejudice and discrimination against Haitians in San Benito, respectively. The question for the fourth dependent variable is: "In general, is your opinion about Haitians 'very negative,' 'negative,' 'neither negative nor positive,' "positive or very positive?"' I dichotomized this variable with "no negative" as the reference category. I collapsed options "very negative" and "negative," and recoded them as one; and options "neither negative nor positive" and "positive or very positive," and recoded 
them as zero. The question for the fifth dependent variable is: "Do you avoid Haitians if possible?"12 This is a dichotomous variable with "no" as the reference category. Independent variables

Both surveys included a question about the religion of respondents. I created a dichotomous variable to capture Catholic self-identification or affiliation recoded as one versus all the observations in other categories grouped together as non-Catholics, and recoded as zero. Moreover, I use respondents' skin colour as a proxy for phenotype as a continuous measure. I estimate the association of ethno-racial self-identification and Catholic self-identification net of the impact of skin colour. In this way, we control for the appearance of the respondent when we predict ethno-racial self-identification. I also regard the ethno-racial condition as multidimensional by including skin colour and ethnic self-identification as regressors in the prejudice analyses. Both surveys gather skin colour data using the LAPOP palette. ${ }^{13}$ I discarded an observation with missing values for skin colour in the LAPOP survey (only one after discarding observations with missing values for ethno-racial self-identification), and 63 observations with missing values for skin colour in the San Benito survey. I also control for female interviewer with LAPOP, and insider interviewer with San Benito (a local interviewer with a preceding social relationship with the respondent) because they are significantly associated with skin colour categorization (analyses not presented in this study).

Moreover, I include a binary variable that measures the frequency of attendance at religious services in the analyses. The main analytic objective is to examine whether individuals who self-identify as Catholic have greater odds of DAC self-identification, and being prejudiced against Haitians compared to non-Catholics. However, it is necessary to examine if these associations are significant net of the impact of religious practice, which may work as a separate 
ideological vehicle of Dominicanidad beyond the Hispanic heritage. In both surveys, respondents were asked how frequently they attended at religious services. I grouped categories "more than once a week" and "once a week," and recoded them as one. I grouped the rest of the categories (for three times a month or less), and recoded them as zero. Practicing Catholics are expected to attend at Mass every Sunday (at least once a week).

Considering the central role of education in the promotion of mainstream discourses of Dominicanidad (Wigginton 2010), I include categorical variables for educational attainment in the analyses. Respondents were asked to indicate the last year of education that they had completed. I grouped individuals who had completed 11 years or fewer to create a category for incomplete secondary education or less; 13 to 16 years for some university or technical degree; and 17 years and over for complete university or more. Individuals who completed 12 years were grouped in the category complete secondary education. I discarded observations with missing values for educational attainment in the LAPOP survey. Using this survey, I included dummy variables for female (versus male) and rural (versus urban), and age as a continuous variable. I also created binary variables for region: metropolitan area, north, east, and south. Moreover, I separated Santo Domingo from the rest of the metropolitan area due to its centrality as the context where mainstream Dominicanidad has been forged.

Furthermore, I treat household income -a nine-category ordinary variable- as a continuous variable that I include in the analysis of national-level prejudice. I used the midpoint of each income category, except for the top, open-ended category, for which I added 16,150 pesos (the difference between the two previous midpoints) to the lower bound of the open-ended category (60,800 pesos). I computed the natural logarithm, and inputted income averages 
according to educational attainment (estimated with an ordinary least squares regression) for 155 missing values.

Analytic plan

In this study, I use logistic regression models to predict DAC self-identifications and prejudice at the national level and in San Benito. First, I examine the association of DAC selfidentifications with Catholic self-identification using (a) LAPOP and (b) San Benito data controlling for skin colour, age, interviewer characteristics, region, rural (in the national-level analysis), and female. I sequentially add control variables for attendance at religious services (Models 2a and 2b), and educational attainment (Models 3a and 3b). Due to the unexpected findings explained below, I extend the analyses with a multinomial regression model predicting self-identification as white, indio/mestizo, and mulato as compared to black using a regional subsample obtained from the LAPOP data: Dominicans who live in Santo Domingo.

Second, I examine the national-level associations of Catholic self-identification with two different dimensions of prejudice: against the citizenship rights of Dominicans of Haitian descent, and against granting work permits to undocumented Haitians who live in the Dominican Republic. I control for skin colour and DAC self-identifications, age, female interviewer, region, rurality, and female. Then, I sequentially add variables for attendance at religious services (Models 5a and 8a), and educational attainment and household income (Models 6a and 9a). ${ }^{14}$ Third, I examine the associations of Catholic self-identification with prejudice and discrimination against Haitians in San Benito. The baseline models include variables for skin colour and DAC self-identifications, age, insider interviewer, and female. Then, I sequentially add variables for attendance at religious services (Models $5 \mathrm{~b}$ and $8 \mathrm{~b}$ ), and educational attainment (Models 6b and 9b). 


\section{Results}

Do individuals who self-identify as Catholic self-identify more with classifications that downplay their own Afro characteristics compared to non-Catholics?

Table 1 presents the coefficients of logistic regression models converted to odds ratios predicting DAC self-identifications at the national level (Models 1a, 2a, 3a) and in San Benito (Models 1b, 2b, 3b). Unexpectedly, I find no national-level evidence of a significant association between Catholic self-identification and DAC self-identifications. Only skin colour seems to be a significant predictor of national-level ethno-racial self-identification: the darker the respondent, the lower the odds of self-identifying as DAC.

\section{$* * * \mathrm{TABLE} * 1 * * *$}

Nevertheless, I find evidence of a direct association between Catholic self-identification and DAC self-identification in San Benito (H1). In this region, the odds of self-identifying as DAC are 79 per cent higher for women who self-identify as Catholic compared to non-Catholics (1.785-1 in Model 3b) net of the impact of skin colour, educational attainment and other sociodemographic characteristics. Moreover, education is significantly associated with DAC self-identification in San Benito. The odds of self-identifying as DAC are 50 per cent lower for individuals who attained complete university or more (1-0.497 in Model 3b) compared to individuals who have not attained complete secondary education. This finding supports the argument that better educated Dominicans are more inclined to accept their Afro ancestry without fear of discrimination (Howard 2001; Roth 2013).

The national-level association between Catholic self-identification and DAC selfidentification is likely not significant for several reasons. DAC identities are probably also shaped by secular perspectives brought about by unexamined dynamics of urbanization and 
modernity. Accordingly, the significance of Catholicism as a cultural component of Dominican identities could be mainly historical. Moreover, Dominicans may understand Catholicism as a component of Dominicanidad significantly distinct from their own ethno-racial identities and beliefs. Furthermore, Dominicans could have acknowledged the commitments of the Catholic Church with civil society as socially meaningful beyond local ethno-racial issues. Alternatively, these commitments also could have supported victims of ethno-racial discrimination such as dark-skinned Dominicans and Haitian immigrants despite the anti-Haitian sentiment openly expressed by certain Catholic authorities.

While these explanations are plausible, the contrasting findings in San Benito suggest that the influence of Catholicism on DAC self-identifications may be particularly different in urban areas. Consequently, I fit another regression model with a regional subsample of Dominicans in Santo Domingo. Santo Domingo is a relevant research setting for this analysis as the historical headquarters of the Catholic hierarchy (Betances 2009; Pérez Memén 2010). Events that reveal the influential role of the Catholic Church are particularly noteworthy in the capital city (Riggio 2015). I examine the association of Catholic self-identification with ethnoracial self-identification in Santo Domingo using a multinomial logistic regression model predicting self-identification as white, indio/mestizo, and mulato as compared to black (Table 1). The specification of this model is similar to the specifications of Models $3 \mathrm{a}$ and $3 \mathrm{~b}$.

In Santo Domingo, the association between Catholic self-identification and ethno-racial self-identification is, as expected, positive and significant for individuals who self-identify as indio and mulato as compared to black (H1). The risk of self-identifying as indio and mulato versus black is about 200 per cent higher for individuals who self-identify as Catholic compared to non-Catholics (3.082-1 and 3.224-1, respectively). This association is not significant for 
individuals who self-identify as white versus black. White self-identification is mainly supported by a whiter skin colour as it is suggested by its lower relative risk ratio. Moreover, the coefficient of attaining complete university or more for individuals who self-identify as indio versus black is consistent in direction with the corresponding coefficient in the San Benito analysis, but not in magnitude. The risk of self-identifying as indio versus black is 94 per cent lower for individuals who attained complete university or more (1-0.056), and 75 per cent lower for individuals who attained some university or technical degree (1-0.253) compared to individuals who have not attained complete secondary education.

Are individuals who self-identify as Catholic significantly more prejudiced against Haitians compared to non-Catholics?

Table 2 presents the coefficients of logistic regression models converted to odds ratios predicting national-level attitudes against the citizenship rights of Dominicans of Haitian descent, and against granting work permits to undocumented Haitians. Unexpectedly, I find no evidence of a significant association between Catholic self-identification and attitudes against the rights of Dominicans of Haitian descent. The negative but low and statistically insignificant coefficient of Catholic self-identification might reveal the contrasting sentiments toward Dominicans of Haitian descent of progressive versus conservative positions. Possibly the emphasis on the family as the core unity of society promoted by the Catholic Church via the media and religious practice has been insufficient to convince a greater number of Catholics of advocating the citizenship rights of these Dominicans.

$* * * \operatorname{TABLE} * 2 * * *$

It is also noteworthy that DAC self-identifications and skin colour are directly associated with attitudes against the citizenship rights of Dominicans of Haitian descent when they are 
concurrently examined. These findings seem contradictory if ethno-racial self-identification and skin colour are mere indicators of race. However, in this study, they represent distinct ethnoracial characteristics that are conceptually and empirically different. Individuals who selfidentify as DAC have greater odds of being against the citizenship rights of Dominicans of Haitian descent than individuals who self-identify as Afro. Beyond this association, a darker skin colour gradually increases the odds of being against the rights of these Dominicans. However, this association becomes marginally significant after controlling for educational attainment and income (Model 6a).

Unlike the association between Catholic self-identification and attitudes against the citizenship rights of Dominicans of Haitian descent, the national-level association between Catholic self-identification and attitudes against granting work permits to undocumented Haitians is, as expected, positive and significant $(\mathbf{H 2})$. Model 9a suggests that individuals who self-identify as Catholic have 38 per cent greater odds of being against granting work permits to undocumented Haitians than individuals who self-identify as non-Catholic (1.377-1). Model 9a also suggests that the effect of attendance at religious services significantly lowers the odds of being against the work permits to undocumented Haitians in 24 per cent (1-0.759). Nonetheless, the interaction between Catholic self-identification and attendance is statistically insignificant (not presented in these models). Moreover, the coefficient of DAC self-identifications is significant and greater than the impact of Catholic self-identification in every regression model. However, the effect of skin colour on attitudes against granting work permits is not significant.

$* * * \mathrm{TABLE} * 3 * * *$

Table 3 presents the coefficients of logistic regression models converted to odds ratios predicting prejudice and discrimination against Haitians in San Benito. As expected, Models $6 \mathrm{~b}$ 
and $9 \mathrm{~b}$ suggest that women who self-identify as Catholic in San Benito are three times as likely to be prejudiced against Haitians (3.128), and two times as likely (2.118) to avoid Haitians when compared to non-Catholic women, respectively (H2). Contrary to the national-level findings in the analysis of attitudes against granting work permits, Model $6 \mathrm{~b}$ suggests that attendance at religious services increases the odds of being prejudiced in 35 per cent (1.349-1) among women in San Benito. However, the impact of attendance at religious services on discrimination against Haitians is not significant.

DAC self-identifications are not significantly associated with prejudice and discrimination against Haitians. This regional finding contrasts with the national-level association between DAC self-identifications and prejudice. The association of skin colour and discrimination is also statistically insignificant. Skin colour is directly associated with prejudice against Haitians only in Models $4 \mathrm{~b}$ and 5b: a darker skin colour category increases the odds in 11 per cent (1.107-1). However, this association becomes insignificant after educational attainment is incorporated in Model 6b. It is noteworthy that, in San Benito, educational attainment lowers the odds of feeling prejudiced, and the odds of discriminating against Haitians with respect to the incomplete secondary education or less category.

A relevant limitation is that the San Benito sample only includes women. Nonetheless, I find no evidence of significant differences by gender in the national-level analyses of DAC selfidentification and prejudice. Consequently, I conclude that the San Benito findings are informative of these dynamics in a specific urban area relatively close to the border. In addition, the Santo Domingo subsample has a limited number of observations $(N=265)$. This study may establish the need to gather more data in Santo Domingo that will allow us to revise these findings. 


\section{Discussion}

Although I find no national-level evidence of significant differences in DAC selfidentifications by Catholic affiliation, this association is significant and positive in two Dominican urban areas: in San Benito, a small urban area in the Northwestern Dominican sierra, and in Santo Domingo, the capital city. It is noteworthy that this association is positive and significant in two urban areas because urbanization is commonly tied with secularization. The statistically insignificant coefficient of "rural" in the national-level analysis and the difference in levels of urbanization between San Benito and Santo Domingo imply other plausible reasons. Possibly the association is significant in Santo Domingo due to the well-established presence of the Catholic hierarchy in the capital (Betances 2009; Riggio 2015). Furthermore, the influence of Catholic discourses may be stronger in urban areas close to the Haitian border. Consequently, it is necessary to examine the dynamics of DAC self-identifications not only at the national level, but also in different regions. The impact of Catholic affiliation may not be relevant in regions with an inferior presence of Catholic hierarchical institutions, where local priests may not systematically criticize syncretism and alternative religious practices.

Moreover, the predicted probabilities of DAC self-identifications for Catholics and nonCatholics, while holding other variables at their means, are high: 0.96 and 0.95 , respectively (Model 3a). Most Catholics and non-Catholics self-identify as DAC at the national level. Further research is needed to identify specific mechanisms of ethno-racial identity formation in association with Catholicism. It is necessary to investigate whether there are other cultural determinants of DAC self-identifications among non-Catholics beyond their embodied ethnoracial characteristics. It is also necessary to examine whether alternative discourses of Dominicanidad that advocate unconventional redefinitions of mulataje or transnational schemas 
(Ricourt 2016; Roth 2013; Simmons 2005) are significantly changing the meaning of hegemonic racial schemas. Relatedly, non-Catholics in Santo Domingo and San Benito may be more inclined to self-identify as Afro compared to Catholics because they may better identify with alternative, less traditional definitions of Dominicanidad.

Individuals who self-identify as Catholic hold more anti-Haitian sentiments than nonCatholics at the national level, and in San Benito. However, Catholics and non-Catholics are equally likely to be against the citizenship rights of Dominicans of Haitian descent. The predicted probabilities of these variables while holding the other variables at their means are 0.54 and 0.56, respectively (Model 6a). Dominican Catholics might not like Haitian culture, but might be inclined to accept that undocumented Dominicans of Haitian descent are indeed Dominicans, and that Dominicanidad is affected by the Haitian presence in an inexorable way. Moreover, non-Catholics may feel threatened by the presence of Dominicans of Haitian descent to the extent that the former would support policies against the latter.

In addition, the association of religiosity with prejudice in these analyses varies according to the dimension of prejudice and region. It is statistically insignificant in the analysis of citizenship rights of undocumented Dominicans of Haitian descent, but it is negative in the analysis of work permits to undocumented Haitians, and positive in the analysis of prejudice in San Benito. Possibly these unclear findings reflect contrasting discourses promoted by religious institutions in different settings.

\section{Conclusion}

This study underscores the relevance of the historical and complex intertwinement of Catholicism as Western cultural heritage, ethno-racial beliefs, and prejudice for the analysis of ethno-racial issues in Latin America. Catholicism in the Dominican Republic downplays Afro- 
Dominican heritage by supporting the construction of Dominican identifications that emphasize hybridity in Santo Domingo and San Benito, and by fostering anti-Haitian sentiments at the national level and in San Benito. This study has an implication for the analysis of the influence of Catholicism in Latin America, and other former colonies of Spain and Portugal. It is not safe to assume (or imply) that Catholicism does not influence the development of DAC identities in the Dominican Republic based on the absence of national-level evidence. Instead, it is necessary to consider competing perspectives within the local Catholic Church, and to examine regional differences that are likely connected to these perspectives. Studying this influence in Santo Domingo is analytically relevant due to the historical roots and the power of the Catholic hierarchy in the capital.

Moreover, this study has several implications for Dominican authorities. They should acknowledge the importance of vindicating Afro-Dominicanidad because it permeates local culture regardless of the influence of mainstream mestizaje ideologies. While the well-ingrained hybrid identities have subjectively softened the degrees of Afro characteristics, the former tacitly underline the significant stigmatization of the latter. This problem affects not only Haitians, but also most non-white Dominicans who also embody these traits in different degrees regardless of self-identification. Local policies should address educational and cultural objectives that inculcate positive conceptualizations of Afro-Dominicanidad. These conceptualizations should underline the value and contribution of Afro heritages to the Dominican Republic as well as narratives that constructively highlight historical and contemporary depictions of DominicanHaitian relations. These educational policies should aim to progressively challenge views that are rooted in colonial beliefs. 


\section{Acknowledgements}

I am deeply grateful to Alex Weinreb for sharing the San Benito data used in this study and for his helpful feedback. I also thank Néstor Rodríguez, Daniel Powers, the editors of Ethnic and Racial Studies, and the anonymous reviewers for their comments. Furthermore, I thank the Latin American Public Opinion Project (LAPOP), its major supporters (the United States Agency for International Development, the United Nations Development Program, the Inter-American Development Bank, and Vanderbilt University), Edward Telles, and the Project on Ethnicity and Race in Latin America (PERLA) for making the data available. Earlier versions of this paper were presented at the 2015 Congress of the Latin American Studies Association and the 2015 Population Association of America Annual Meeting.

\section{Funding}

The San Benito survey was funded by a grant awarded by the National Institute of Child Health and Human Development [1R21HD054731-01A1] to Mariano Sana (P.I.) and co-P.I.s Alexander Weinreb and Guy Stecklov.

\section{Notes}

1. Mestizaje (Spanish) means ethno-racial mixture. Mestizaje ideologies in Latin America have disseminated discourses that underscore the positive value derived from racial mixing for incorporating indigenous and Afro-descendant populations in processes of nation-making (see Paredes 2017, 2018).

2. Henceforth, I use the term Afro to refer to the physical and cultural traits of Afrodescendants, as it is used in many Latin American countries.

3. The Concordat with the Vatican established during Trujillo's regime still benefits the Dominican Catholic Church (e.g., via tax exemptions).

4. See, for instance, Jesuit projects that seek to help immigrants founded on intercultural objectives: Centro Bonó (http://bono.org.do), Centro de Formación y Acción Social y 
Agraria (http://cefasa.com/), or their collaborative efforts with other not-for-profit Catholic organizations (e.g., Obra de Cooperación Apostólica Seglar Hispanoamericana: http://www.ocasha-ccs.org/).

5. The unification of Hispaniola refers to the forceful annexation of Republic of Spanish Haiti into Haiti.

6. The relationship between Trujillo and the Catholic Church began to deteriorate by the end of the 1950s. After the regime, the political mediation of the Catholic hierarchy contributed to the legitimation of subsequent authoritarian governments. Nevertheless, a smaller section of the Dominican Catholic Church established a new alternative orientation founded on principles of social justice (Betances 2009).

7. This use contrasts with the use of indio in other indo-Latin American countries, which refers pejoratively to indigenous populations (Paredes 2018).

8. Racial projects highlight the relevance of ideologies as instruments of domination. Accordingly, Dominicans are influenced by mainstream Dominicanidad shaped as a racial project. This influence should not be interpreted as Dominicans' denial of their "true" Afro identities (Wheeler 2015). Dominicans also have developed alternative discourses that counter mainstream Dominicanidad in different ways (Ricourt 2016; Simmons 2005).

9. I also fitted multinomial regression models with a nominal dependent variable with four categories: white, indio/mestizo, mulato, and black/Afro-Dominican. Based on these analyses, I decided to use a binary dependent variable as the optimal choice for this study. I also translated negro as black in order to connect the Afro-Dominican condition with the analytic notion of blackness. Nevertheless, it is necessary to mention that negro, as in other mestizaje contexts, can be interpreted in different ways (García-Peña 2015). 
10. In Spanish: “ ¿Hasta qué punto está de acuerdo con que los hijos de inmigrantes haitianos nacidos en la República Dominicana sean ciudadanos dominicanos?," and “¿Hasta qué punto está de acuerdo o desacuerdo con que el gobierno dominicano otorgue permisos de trabajo a los haitianos indocumentados que viven en República Dominicana?"

11. I fitted ordered logistic regression models to predict prejudice against the citizenship of Dominican Republic-born children of Haitian immigrants, and prejudice against work permits for undocumented Haitians who live in the Dominican Republic. These models, however, did not satisfy the proportional odds assumption even after I collapsed the number of categories in different ways. Therefore, I dichotomized these variables.

12. I translated the questions from Spanish to English. "En general, su opinión sobre los haitianos es muy negativa, negativa, ni negativa ni positiva, positiva o muy positiva" "Si es posible, ¿los evita? (a los haitianos)”.

13. See http://perla.princeton.edu/surveys/perla-color-palette/. I recoded this variable using zero for the lightest and grouped categories 8 and over for the darkest skin tone.

14. I did not include household income in the analyses of self-identification because its coefficient was statistically insignificant. The results presented in these analyses were not different after income was included as an independent variable. 


\section{References}

Betances, Emelio. 2009. La Iglesia Católica y la politica del poder en América Latina: el caso dominicano en perspectiva comparada. 2nd ed. Santo Domingo: Fundación Global Democracia y Desarrollo.

Candelario, Ginetta E. B. 2007. Black behind the Ears: Dominican Racial Identity from Museums to Beauty Shops. Durham, NC: Duke University Press.

Duany, Jorge. 2006. "Racializing Ethnicity in the Spanish-Speaking Caribbean." Latin American and Caribbean Ethnic Studies 1(2): 231-248.

Flórez-Estrada, María. 2008. “Epistemología y dominación: la marca en de las Casas y de Sepúlveda." Revista de Ciencias Sociales 122(IV): 133-147.

Fredrickson, George M. 2003. Racism: A Short History. Princeton, NJ: Princeton University Press.

García-Peña, Lorgia. 2015. “Translating Blackness: Dominicans Negotiating Race and Belonging." The Black Scholar 45(2): 10-20.

Horn, Maja. 2010. "Queer Dominican Moves: In the Interstices of Colonial Legacies and Global Impulses." In Development, Sexual Rights, and Global Governance, edited by Amy Lind, 169-181. New York: Routledge.

Howard, David. 2001. Coloring the Nation: Race and Ethnicity in the Dominican Republic. Boulder, CO: Lynne Rienner.

LAPOP. 2010. The AmericasBarometer by the Latin American Public Opinion Project (LAPOP), 2010 Survey for Dominican Republic (http://www.LapopSurveys.org).

Martínez, Samuel. 2003. "Not a Cockfight: Rethinking Haitian-Dominican Relations." Latin American Perspectives 30(3): 80-101.

Martínez, Samuel, and Bridget Wooding. 2017. "El antihaitianismo en la República Dominicana: ¿un giro biopolítico?” Migración y Desarrollo 15(28): 95-123.

Mayes, April J. 2014. The Mulatto Republic: Class, Race, and Dominican National Identity. Gainesville, FL: University Press of Florida.

Morgan, Brendan. Forthcoming. "Antihaitianismo: An Embodied Discourse." Ethnic and Racial Studies DOI:10.1080/01419870.2018.1430841.

Omi, Michael, and Howard Winant. 1994. Racial Formation in the United States: From the 1960s to the 1980s. New York: Routledge. 
Paredes, Cristian L. 2017. "Mestizaje and the Significance of Phenotype in Guatemala." Sociology of Race and Ethnicity 3(3): 319-37.

Paredes, Cristian L. 2018. "Multidimensional Ethno-racial Status in Contexts of Mestizaje: Ethno-racial Stratification in Contemporary Peru." Socius 4:10.1177/2378023118762002.

Pérez Memén, Fernando A. 2010. "El indio y el negro en la visión de la Iglesia y el Estado en Santo Domingo (siglos XVI-XVIII)." Revista de Historia de América 143 (juliodiciembre): 99-115.

Religión Digital. 2014. "Cardenal López Rodríguez llama 'sinvergüenza' al jesuita Mario Serrano.” February 8. Retrieved September 5, 2014 (http://www.periodistadigital.com/religion/america/2014/02/08/cardenal-lopez-rodriguezllama-sinverguenza-al-jesuita-mario-serrano-iglesia-religion-dios-dominicanahaiti.shtml).

Ricourt, Milagros. 2016. The Dominican Racial Imaginary: Surveying the Landscape of Race and Nation in Hispaniola. New Brunswick, NJ: Rutgers University Press.

Riggio, Guido. 2015. “El Estado Dominicano ¿Laico o aconfesional?,” Acento, May 26. Retrieved June 11, 2018 (https://acento.com.do/2015/opinion/8251783-el-estadodominicano-laico-o-aconfesional/).

Roth, Wendy D. 2012. Race Migrations: Latinos and the Cultural Transformation of Race. Stanford: Stanford University Press.

Roth, Wendy D. 2013. “A Single Shade of 'Negro': Henry Louis Gates' Depictions of Blackness in the Dominican Republic." Latin American and Caribbean Ethnic Studies 8(1): 92-96.

Sáez, José Luis, s.j. 1988. "Catolicismo e hispanidad en la oratoria de Trujillo." Estudios Sociales 21 (julio-setiembre): 89-104.

Sagás, Ernesto. 2000. Race and Politics in the Dominican Republic. Gainesville: University Press of Florida.

Sana, Mariano, Guy Stecklov, and Alexander A. Weinreb. 2016. "A Test of the Stranger-Interviewer Norm in the Dominican Republic." Population Studies 70(1): 7392.

Simmons, Kimberly E. 2005. “'Somos una Liga': Afro-Dominicanidad and the Articulation of New Racial Identities in the Dominican Republic." Wadabagei 8(1): 5164.

Torres-Saillant, Silvio. 1998. "The Tribulations of Blackness: Stages in Dominican Racial Identity." Latin American Perspectives 25(3): 126-146. 
Vargas Llosa, Mario. 2003 [2001]. The Feast of the Goat. London: Faber and Faber.

Vargas Llosa, Mario. 2013. "Los Parias del Caribe," El País, November 3. Retrieved November 6, 2013 (http://elpais.com/elpais/2013/10/31/opinion/1383233998 -965346.html).

Wiarda, Howard J. 1965. "The Changing Political Orientation of the Catholic Church in the Dominican Republic.” Journal of Church and State 7(2): 238-254.

Wheeler, Eva M. 2015. "Race, Legacy, and Lineage in the Dominican Republic: Shifting Paradigms." The Black Scholar 45(2): 34-44.

Wigginton, Sheridan. 2010. "Blackness as a Barrier to Citizenship and Education: Situating the Example of Dilcia Yean and Violeta Bosico." Education, Citizenship and Social Justice 5(2): 163-170.

Winters, Cecilia A. and Robert Derrell. 2010. "Divided Neighbors on an Indivisible Island: Economic Disparity and Cumulative Causation on Hispaniola." Journal of Economic Issues XLIV(3): 597-613.

Wooding, Bridget, and Allison J. Petrozziello. 2013. "New Challenges for the Realisation of Migrants' Rights Following the Haiti 2010 Earthquake: Haitian Women on the Borderlands." Bulletin of Latin American Research 32(4): 407-420. 
Table 1. Coefficients of (1) logistic regression models (odds ratios) predicting ethno-racial identifications that downplay Afro characteristics (reference: Afro self-identification) at the national level (Models 1a, 2a, 3a) and in San Benito (Models 1b, 2b, 3b); and (2) a multinomial logistic regression model (relative risk ratios) predicting ethno-racial self-identification in Santo Domingo (reference: black)

\begin{tabular}{|c|c|c|c|c|c|c|c|c|c|}
\hline \multirow{2}{*}{ Variables } & \multicolumn{6}{|c|}{ (1) Logistic Regression Models } & \multicolumn{3}{|c|}{ (2) Multinomial Logistic Model } \\
\hline & Model 1a & Model 1b & Model 2a & Model 2b & Model 3a & Model 3b & White & Indio/Mestizo & Mulato \\
\hline Respondents' Skin Colour & $\begin{array}{l}0.422 * * * \\
(0.03)\end{array}$ & $\begin{array}{l}0.420 * * * \\
(0.06)\end{array}$ & $\begin{array}{l}0.422 * * * \\
(0.03)\end{array}$ & $\begin{array}{l}0.420 * * * \\
(0.06)\end{array}$ & $\begin{array}{l}0.414 * * * \\
(0.03)\end{array}$ & $\begin{array}{l}0.403 * * * \\
(0.06)\end{array}$ & $\begin{array}{l}0.143 * * * \\
(0.04)\end{array}$ & $\begin{array}{l}0.384 * * * \\
(0.06)\end{array}$ & $\begin{array}{l}0.497 * * * \\
(0.09)\end{array}$ \\
\hline Age & $\begin{array}{l}0.993 \\
(0.01)\end{array}$ & $\begin{array}{l}1.025^{*} \\
(0.01)\end{array}$ & $\begin{array}{l}0.994 \\
(0.01)\end{array}$ & $\begin{array}{l}1.024 * \\
(0.01)\end{array}$ & $\begin{array}{l}0.991 \\
(0.01)\end{array}$ & $\begin{array}{l}1.028 * \\
(0.01)\end{array}$ & $\begin{array}{l}0.970 \\
(0.02)\end{array}$ & $\begin{array}{l}0.959 * \\
(0.02)\end{array}$ & $\begin{array}{l}0.953 * \\
(0.02)\end{array}$ \\
\hline $\begin{array}{l}\text { Catholic Self-Identification } \\
\text { (Reference: Other Religious Identifications) }\end{array}$ & $\begin{array}{l}1.358 \\
(0.31)\end{array}$ & $\begin{array}{l}1.892 * \\
(0.52)\end{array}$ & $\begin{array}{l}1.351 \\
(0.30)\end{array}$ & $\begin{array}{l}1.929 * \\
(0.56)\end{array}$ & $\begin{array}{l}1.351 \\
(0.30)\end{array}$ & $\begin{array}{l}1.785^{*} \\
(0.50)\end{array}$ & $\begin{array}{l}1.971 \\
(1.09)\end{array}$ & $\begin{array}{l}3.082^{*} \\
(1.52)\end{array}$ & $\begin{array}{l}3.224 * \\
(1.70)\end{array}$ \\
\hline $\begin{array}{l}\text { Attendance at Religious Services } \\
\text { (Reference: Three Times a Month or Less) }\end{array}$ & & & $\begin{array}{l}0.741 \\
(0.19)\end{array}$ & $\begin{array}{l}1.105 \\
(0.28)\end{array}$ & $\begin{array}{l}0.739 \\
(0.19)\end{array}$ & $\begin{array}{l}1.128 \\
-0.29\end{array}$ & $\begin{array}{l}0.627 \\
(0.62)\end{array}$ & $\begin{array}{l}0.678 \\
(0.46)\end{array}$ & $\begin{array}{l}0.449 \\
(0.26)\end{array}$ \\
\hline \multicolumn{10}{|l|}{ Educational Attainment } \\
\hline Complete Secondary Education & & & & & $\begin{array}{l}0.695 \\
(0.21)\end{array}$ & $\begin{array}{l}1.098 \\
(0.40)\end{array}$ & $\begin{array}{l}0.075+ \\
(0.12)\end{array}$ & $\begin{array}{l}0.397 \\
(0.27)\end{array}$ & $\begin{array}{l}0.744 \\
(0.42)\end{array}$ \\
\hline Some University or Technical Degree & & & & & $\begin{array}{l}0.879 \\
(0.32)\end{array}$ & $\begin{array}{l}0.916 \\
(0.28)\end{array}$ & $\begin{array}{l}0.366 \\
(0.33)\end{array}$ & $\begin{array}{l}0.253^{*} \\
(0.15)\end{array}$ & $\begin{array}{l}0.485 \\
(0.27)\end{array}$ \\
\hline Complete University or More & & & & & $\begin{array}{l}0.520 \\
(0.21)\end{array}$ & $\begin{array}{l}0.497 * \\
(0.16)\end{array}$ & $\begin{array}{l}0.255 \\
(0.23)\end{array}$ & $\begin{array}{l}0.056^{* * * *} \\
(0.04)\end{array}$ & $\begin{array}{l}0.278 \\
(0.23)\end{array}$ \\
\hline Log-Pseudolikelihood & -354.66 & -259.24 & -353.57 & -259.16 & -351.77 & -256.55 & & -225.56 & \\
\hline $\mathrm{N}$ & 1455 & 1144 & 1455 & 1144 & 1455 & 1144 & & 265 & \\
\hline
\end{tabular}

Notes: Skin colour categories are ordered from whitest to darkest with the darkest category assigned the highest value. Robust standard errors adjusted for within-interviewer clustering are in parentheses. Dashes indicate reference categories. Estimated intercepts and coefficients (odds ratios) of region (Metropolitan area without Santo Domingo, North, East, and South with Santo Domingo as the reference category), rural, female and female interviewer in Models 1a, 2a, and 3a, and insider interviewer in Models 1b, 2b, and 3b are omitted to save space. Estimated coefficients (relative risk ratios of multinomial logistic regression model) of female and female interviewer are omitted to save space. These coefficients are not statistically significant.

$+p<.1 ; * p<.05 ; * * p<.01 ; * * * p .001$ (two-tailed tests) 
Table 2. Coefficients (odds ratios) of logistic regression models predicting national-level prejudice against Haitians

\begin{tabular}{|c|c|c|c|c|c|c|}
\hline \multirow[t]{2}{*}{ Variables } & \multicolumn{3}{|c|}{$\begin{array}{c}\text { (1) Citizenship Rights of Dominicans } \\
\text { of Haitian Descent }\end{array}$} & \multicolumn{3}{|c|}{$\begin{array}{l}\text { (2) Granting Work Permits to } \\
\text { Undocumented Haitians }\end{array}$} \\
\hline & Model 4a & Model 5a & Model 6a & Model 7a & Model 8a & Model 9a \\
\hline $\begin{array}{l}\text { DAC Identification } \\
\text { (Reference: Afro Ethnic Identification) }\end{array}$ & $\begin{array}{l}2.046^{* * *} \\
(0.36)\end{array}$ & $\begin{array}{l}2.045^{* * *} \\
(0.36)\end{array}$ & $\begin{array}{l}1.986^{* * *} \\
(0.35)\end{array}$ & $\begin{array}{l}1.893 * * \\
(0.43)\end{array}$ & $\begin{array}{l}1.872 * * \\
(0.43)\end{array}$ & $\begin{array}{l}1.837^{*} \\
(0.44)\end{array}$ \\
\hline Respondents' Skin Colour & $\begin{array}{l}1.101^{*} \\
(0.04)\end{array}$ & $\begin{array}{l}1.101^{*} \\
(0.04)\end{array}$ & $\begin{array}{l}1.067+ \\
(0.04)\end{array}$ & $\begin{array}{l}1.073 \\
(0.05)\end{array}$ & $\begin{array}{l}1.077 \\
(0.05)\end{array}$ & $\begin{array}{l}1.046 \\
(0.05)\end{array}$ \\
\hline Age & $\begin{array}{l}1.009^{*} \\
(0.004)\end{array}$ & $\begin{array}{l}1.010^{*} \\
(0.004)\end{array}$ & $\begin{array}{l}1.005 \\
(0.005)\end{array}$ & $\begin{array}{l}1.002 \\
(0.003)\end{array}$ & $\begin{array}{l}1.003 \\
(0.003)\end{array}$ & $\begin{array}{l}1.000 \\
(0.003)\end{array}$ \\
\hline $\begin{array}{l}\text { Catholic Self-Identification } \\
\text { (Reference: Other Religious Identifications) }\end{array}$ & $\begin{array}{l}0.959 \\
(0.10)\end{array}$ & $\begin{array}{l}0.959 \\
(0.10)\end{array}$ & $\begin{array}{l}0.939 \\
(0.09)\end{array}$ & $\begin{array}{l}1.418^{* * *} \\
(0.14)\end{array}$ & $\begin{array}{l}1.414 * * * \\
(0.14)\end{array}$ & $\begin{array}{l}1.377 * * * \\
(0.13)\end{array}$ \\
\hline $\begin{array}{l}\text { Attendance at Religious Services } \\
\text { (Reference: Three Times a Month or Less) }\end{array}$ & & $\begin{array}{l}0.994 \\
(0.10)\end{array}$ & $\begin{array}{l}0.976 \\
(0.10)\end{array}$ & & $\begin{array}{l}0.773^{*} \\
(0.09)\end{array}$ & $\begin{array}{l}0.759^{*} \\
(0.08)\end{array}$ \\
\hline \multicolumn{7}{|l|}{ Educational Attainment } \\
\hline $\begin{array}{l}\text { Incomplete Secondary Education or Less } \\
\text { Complete Secondary Education }\end{array}$ & & & $\begin{array}{l}\quad- \\
0.531 * * * \\
(0.10)\end{array}$ & & & $\begin{array}{c}- \\
0.801 \\
(0.12)\end{array}$ \\
\hline Some University or Technical Degree & & & $\begin{array}{l}0.793 \\
(0.15)\end{array}$ & & & $\begin{array}{l}0.748 \\
(0.14)\end{array}$ \\
\hline Complete University or More & & & $\begin{array}{l}0.686+ \\
(0.14)\end{array}$ & & & $\begin{array}{l}0.771 \\
(0.22)\end{array}$ \\
\hline Logged Income & & & $\begin{array}{l}0.854 * \\
(0.05)\end{array}$ & & & $\begin{array}{l}0.812^{*} \\
(0.07)\end{array}$ \\
\hline \multicolumn{7}{|l|}{ Region } \\
\hline Santo Domingo & - & - & - & - & - & - \\
\hline $\begin{array}{l}\text { Metropolitan Area } \\
\text { (without Santo Domingo) }\end{array}$ & $\begin{array}{l}1.470+ \\
(0.29)\end{array}$ & $\begin{array}{l}1.470+ \\
(0.29)\end{array}$ & $\begin{array}{l}1.564^{*} \\
(0.30)\end{array}$ & $\begin{array}{l}1.097 \\
(0.27)\end{array}$ & $\begin{array}{l}1.114 \\
(0.27)\end{array}$ & $\begin{array}{l}1.208 \\
(0.28)\end{array}$ \\
\hline North & $\begin{array}{l}1.818^{* *} \\
(0.36)\end{array}$ & $\begin{array}{l}1.818^{* *} \\
(0.36)\end{array}$ & $\begin{array}{l}1.698 * * \\
(0.34)\end{array}$ & $\begin{array}{l}1.636^{*} \\
(0.33)\end{array}$ & $\begin{array}{l}1.636^{*} \\
(0.34)\end{array}$ & $\begin{array}{l}1.509^{*} \\
(0.30)\end{array}$ \\
\hline East & $\begin{array}{l}1.178 \\
(0.16)\end{array}$ & $\begin{array}{l}1.179 \\
(0.16)\end{array}$ & $\begin{array}{l}1.056 \\
(0.12)\end{array}$ & $\begin{array}{l}2.181 * * * \\
(0.51)\end{array}$ & $\begin{array}{l}2.215^{* * *} \\
(0.53)\end{array}$ & $\begin{array}{l}1.965 * * \\
(0.42)\end{array}$ \\
\hline South & $\begin{array}{l}1.303^{*} \\
(0.14)\end{array}$ & $\begin{array}{l}1.303 * \\
(0.14)\end{array}$ & $\begin{array}{l}1.135 \\
(0.11)\end{array}$ & $\begin{array}{l}1.753^{*} \\
(0.42)\end{array}$ & $\begin{array}{l}1.739 * \\
(0.41)\end{array}$ & $\begin{array}{l}1.502+ \\
(0.36)\end{array}$ \\
\hline Rural & $\begin{array}{l}1.391 * \\
(0.23)\end{array}$ & $\begin{array}{l}1.391 * \\
(0.23)\end{array}$ & $\begin{array}{l}1.290 \\
(0.21)\end{array}$ & $\begin{array}{l}0.860 \\
(0.16)\end{array}$ & $\begin{array}{l}0.866 \\
(0.16)\end{array}$ & $\begin{array}{l}0.830 \\
(0.16)\end{array}$ \\
\hline Log-Pseudolikelihood & -958.72 & -958.72 & -944.74 & -912.18 & -909.67 & -900.87 \\
\hline $\mathrm{N}$ & 1426 & 1426 & 1426 & 1426 & 1426 & 1426 \\
\hline
\end{tabular}

Notes: DAC stands for "Downplay Afro Characteristics." Skin colour categories are ordered from whitest to darkest with the darkest category assigned the highest value. Robust standard errors adjusted for within-interviewer clustering are in parentheses. Dashes indicate reference categories. Estimated intercepts and coefficients (odds ratios) of female and female interviewer (not significant) are omitted to save space. $+p<.1 ; * p<.05 ; * * p<.01 ; * * * p<.001$ (two-tailed tests) 
Table 3. Coefficients (odds ratios) of logistic regression models predicting regional-level prejudice and discrimination against Haitians in San Benito

\begin{tabular}{|c|c|c|c|c|c|c|}
\hline \multirow{2}{*}{ Variables } & \multicolumn{3}{|c|}{ Prejudice Against Haitians } & \multicolumn{3}{|c|}{ Discrimination Against Haitians } \\
\hline & Model 4b & Model 5b & Model 6b & Model 7b & Model 8b & Model 9b \\
\hline $\begin{array}{l}\text { DAC Identification } \\
\text { (Reference: Afro Ethnic Identification) }\end{array}$ & $\begin{array}{l}1.381 \\
(0.41)\end{array}$ & $\begin{array}{l}1.376 \\
(0.40)\end{array}$ & $\begin{array}{l}1.313 \\
(0.39)\end{array}$ & $\begin{array}{l}0.803 \\
(0.21)\end{array}$ & $\begin{array}{l}0.803 \\
(0.21)\end{array}$ & $\begin{array}{l}0.785 \\
(0.21)\end{array}$ \\
\hline Respondents' Skin Colour & $\begin{array}{l}1.106^{*} \\
(0.06)\end{array}$ & $\begin{array}{l}1.107^{*} \\
(0.05)\end{array}$ & $\begin{array}{l}1.063 \\
(0.05)\end{array}$ & $\begin{array}{l}1.050 \\
(0.04)\end{array}$ & $\begin{array}{l}1.050 \\
(0.04)\end{array}$ & $\begin{array}{l}1.023 \\
(0.04)\end{array}$ \\
\hline $\begin{array}{l}\text { Catholic Self-Identification } \\
\text { (Reference: Other Religious Identifications) }\end{array}$ & $\begin{array}{l}2.974 * * * \\
(0.72)\end{array}$ & $\begin{array}{l}3.117 * * * \\
(0.74)\end{array}$ & $\begin{array}{l}3.128 * * * \\
(0.75)\end{array}$ & $\begin{array}{l}2.098 * * \\
(0.48)\end{array}$ & $\begin{array}{l}2.095^{* *} \\
(0.49)\end{array}$ & $\begin{array}{l}2.118^{* *} \\
(0.50)\end{array}$ \\
\hline $\begin{array}{l}\text { Attendance at Religious Services } \\
\text { (Reference: Three Times a Month or Less) }\end{array}$ & & $\begin{array}{l}1.273^{*} \\
(0.13)\end{array}$ & $\begin{array}{l}1.349 * * \\
(0.15)\end{array}$ & & $\begin{array}{l}0.992 \\
(0.13)\end{array}$ & $\begin{array}{l}1.028 \\
(0.13)\end{array}$ \\
\hline \multicolumn{7}{|l|}{ Educational Attainment } \\
\hline Incomplete Secondary Education or Less & & & - & & & - \\
\hline Complete Secondary Education & & & $\begin{array}{l}0.575^{* * *} \\
(0.09)\end{array}$ & & & $\begin{array}{l}0.596^{* *} \\
(0.10)\end{array}$ \\
\hline Some University or Technical Degree & & & $\begin{array}{l}0.589 * * \\
(0.12)\end{array}$ & & & $\begin{array}{l}0.619 * \\
(0.13)\end{array}$ \\
\hline Complete University or More & & & $\begin{array}{l}0.302 * * * \\
(0.07)\end{array}$ & & & $\begin{array}{l}0.529 * * * \\
(0.10)\end{array}$ \\
\hline Log-Pseudolikelihood & -664.84 & -663.41 & -645.11 & -740.54 & -740.53 & -731.70 \\
\hline $\mathrm{N}$ & 1143 & 1143 & 1143 & 1144 & 1144 & 1144 \\
\hline
\end{tabular}

Notes: DAC stands for "Downplay Afro Characteristics." Skin colour categories are ordered from whitest to darkest with the darkest category assigned the highest value. Robust standard errors adjusted for within-interviewer clustering are in parentheses. Dashes indicate reference categories.

Estimated intercepts and the coefficients of age and insider interviewer (not significant) are omitted to save space.

$* p<.05 ; * *<.01 ; * * p<.001$ (two-tailed tests) 
Appendix. Summary statistics for the variables used in the analysis

\begin{tabular}{|c|c|c|c|}
\hline Variables & $\begin{array}{l}\text { Dominican Republic } \\
(N=1,455)\end{array}$ & $\begin{array}{l}\text { San Benito } \\
(N=1,144)\end{array}$ & $\begin{array}{l}\text { Santo Domingo } \\
(N=265)\end{array}$ \\
\hline \multicolumn{4}{|l|}{ Dependent Variables } \\
\hline $\begin{array}{l}\text { DAC Identification } \\
\quad \text { (Reference: Afro Ethnic Identification) }\end{array}$ & $\begin{array}{l}89.55 \% \\
10.45 \%\end{array}$ & $\begin{array}{l}92.48 \% \\
7.52 \%\end{array}$ & $\dagger$ \\
\hline $\begin{array}{l}\text { Against Citizenship Rights of Dominicans of } \\
\text { Haitian Descent } \\
\text { (Reference: Not Against Citizenship Rights) }\end{array}$ & $\begin{array}{l}54.63 \% \\
45.37 \%\end{array}$ & - & - \\
\hline $\begin{array}{l}\text { Against Granting Work Permits to } \\
\text { Undocumented Haitians } \\
\text { (Reference: Not Against Granting Work Permits) }\end{array}$ & $\begin{array}{l}63.46 \% \\
36.54 \%\end{array}$ & - & - \\
\hline $\begin{array}{l}\text { Prejudice Against Haitians } \\
\text { (Reference: Not Prejudiced Against Haitians) }\end{array}$ & - & $\begin{array}{l}28.00 \% \\
72.00 \%\end{array}$ & - \\
\hline $\begin{array}{l}\text { Discrimination Against Haitians } \\
\text { (Reference: Does Not Discriminate Against Haitians) }\end{array}$ & - & $\begin{array}{l}36.10 \% \\
63.90 \%\end{array}$ & - \\
\hline \multicolumn{4}{|l|}{ Independent Variables } \\
\hline Respondents' Skin Colour (Mean; S.D.; Min.; Max.) & $(4.04 ; 1.78 ; 0 ; 8)$ & $(4.38 ; 1.39 ; 0 ; 8)$ & $(4.50 ; 1.82 ; 1 ; 8)$ \\
\hline Age (Mean; S.D.; Min.; Max.) & $(41.02 ; 16.65 ; 18 ; 90)$ & $(34.36 ; 8.74 ; 20 ; 51)$ & $(40.68 ; 16.44 ; 18 ; 87)$ \\
\hline $\begin{array}{l}\text { Catholic Self-Identification } \\
\text { (Reference: Other Religious Identifications) }\end{array}$ & $\begin{array}{l}59.24 \% \\
40.76 \%\end{array}$ & $\begin{array}{l}88.11 \% \\
11.89 \%\end{array}$ & $\begin{array}{l}51.32 \% \\
48.68 \%\end{array}$ \\
\hline $\begin{array}{l}\text { Attendance at Religious Services } \\
\text { (Reference: Three Times a Month or Less) }\end{array}$ & $\begin{array}{l}51.55 \% \\
48.45 \%\end{array}$ & $\begin{array}{l}34.44 \% \\
65.56 \%\end{array}$ & $\begin{array}{l}50.94 \% \\
49.06 \%\end{array}$ \\
\hline $\begin{array}{l}\text { Educational Attainment } \\
\text { Incomplete Secondary Education or Less } \\
\text { Complete Secondary Education } \\
\text { Some University or Technical Degree } \\
\text { Complete University or More }\end{array}$ & $\begin{array}{l}66.60 \% \\
16.70 \% \\
10.10 \% \\
6.60 \%\end{array}$ & $\begin{array}{l}38.20 \% \\
14.16 \% \\
28.15 \% \\
19.49 \%\end{array}$ & $\begin{array}{r}59.25 \% \\
21.13 \% \\
12.08 \% \\
7.55 \%\end{array}$ \\
\hline Logged Income & $(8.91 ; 0.89 ; 7.26 ; 11.14)$ & - & - \\
\hline Female & $50.38 \%$ & - & $50.57 \%$ \\
\hline Female Interviewer & $61.58 \%$ & - & $73.58 \%$ \\
\hline Insider Interviewer & - & $18.18 \%$ & - \\
\hline \multicolumn{4}{|l|}{ Region } \\
\hline Santo Domingo & $18.21 \%$ & - & - \\
\hline Metropolitan Area (without Santo Domingo) & $12.78 \%$ & - & - \\
\hline North & $35.95 \%$ & - & - \\
\hline East & $16.01 \%$ & - & - \\
\hline South & $17.04 \%$ & - & - \\
\hline Rural & $26.94 \%$ & - & - \\
\hline
\end{tabular}

Notes: DAC stands for "Downplay Afro Characteristics." Dashes indicate "Not Applicable." Skin colour categories are ordered from whitest to darkest with the darkest category assigned the highest value.

$\dagger$ White $=7.17 \%$; Indio $/$ Mestizo $=60.00 \% ;$ Mulato $=17.74 \%$; Black $=15.09 \%$ 